\title{
Suurten ikäluokkien toinen mahdollisuus?
}

\section{Yliopisto-opintojen aloittaminen myöhäiskeski-iässä}

\author{
NINA HALTTUNEN \& MARIKA ALHO-MALMELIN
}

\begin{abstract}
Artikkelissa tarkastellaan aikuisia, jotka ovat hakeutuneet yliopisto-opiskelijoiksi 50-vuotiaina tai sitä vanhempina. Kysymyksessä on sukupolvi, joka massoitti1960-luvulla yliopistot. Keitä tässä sukupolvessa ovat myöhäiskeski-iällä yliopisto-opintonsa aloittaneet? Ovatko he toisen opiskelumahdollisuuden saaneita vai niitä, jotka jättivät nuorena mahdollisuudensa käyttämättä? Problematiikkaa valotetaan artikkelissa myös tapauskuvauksesta käsin.
\end{abstract}

Y liopistojen opiskelijat ovat viime vuosikymmeninä vanhentuneet, ja yhä kasvava joukko aloittaa tutkinto-opiskelunsa selvästi aikuisella iällä. Aikuisena aloittaneista enemmistö on iältään kolmi-nelikymppisiä. Myöhäisemmässä keski-iässä tai sen jälkeen aloittaneet ovat yliopisto-opiskelijoiden joukossa hyvin pienenä vähemmistönä. Vuonna 2003 kaikista yliopistoihin hakeneista ja hyväksytyistä alle prosentti oli vähintään 50-vuotiaita.

Myöhäiskeski-ikää, ikäkautta 48-56 ikävuoden välillä, voidaan kuvata ensimmäiseksi aidoksi kypsyyden elämänjaksoksi. Tässä ikävaiheessa elämä jäsentyy ja selkeytyy sisäisesti. Myöhäiskeski-iän aikaiset elämänmuutokset rakentuvat kuitenkin eletyn elämän päälle, eivätkä yleensä tee merkittäviä poikkeamia jo olemassa olevasta. Uusi ajanjakso vaikuttaa muutosten suuntaan ja voimaan, jolla niihin suhtaudutaan. Pelko elämäntyön merkityksettömyydestä on tyypillistä tälle ikävaiheelle. (Turunen 2005, 245.) Koko aikuisuus on altista aikaa elämänmuutoksille ja saa ihmisen punnitsemaan elettyä elämäänsä. Koetut elämänmuutokset synnyttävät usein sisäisiä haasteita, jossa elämänsuunnitelmaa muutetaan. Esimerkiksi koulutuksen aloittaminen voi tällöin olla ratkaisu. (Houtsonen 1996.)

Tarkastelemme tässä artikkelissa myöhäiskeski-iässä tai sitä vanhempana aloitetun tutkintoopiskelun merkityksiä. Vanhemmalla iällä aloitetusta tutkinto-opiskelusta puhutaan usein toisena mahdollisuutena. Ovatko suurista ikäluokista toisen mahdollisuuden jäljillä nyt he, jotka nuoruudessaan jäivät koulutusmahdollisuuksista sivuun vai ovatko koulutukseen pyrkivät heitä, jotka nuorinakin kouluttautuivat? Millä merkityksillä yli 50-vuotiaana aloitettu korkeakoulututkinto näyttäytyy toisena mahdollisuutena? Voidaanko ylipäätään puhua toisesta mahdollisuudesta? Pyrimme valottamaan ilmiötä avaamalla kontekstia, jossa nyt yli 50-vuotiaat ovat elämänsä eläneet. Lisäksi tarkoituksenamme on hahmottaa taustaksi elämäntilannetta, jossa nämä aikuiset tällä hetkellä elävät. Yleiskuvan piirtämiseksi tarkastelemme artikkelissamme ensin tilastojen valossa yli 50vuotiaana korkeakoulututkintonsa aloittaneiden taustoja. Kerromme lisäksi yhden yli 50-vuotiaana opiskelunsa korkeakoulussa aloittaneen tarinan ja pyrimme kuvaamaan sen avulla elämänvaihetta suhteessa opintojen aloittamiseen, tutkinnon käyttötarkoituksiin ja sille annettuihin merkityksiin.

\section{Toinen mahdollisuus?}

Tämän päivän 50 vuotta täyttäneet edustavat ikäpolvea, jota voidaan Roosin (1988) tavoin nimittää suuren murroksen sukupolveksi tai Kauppilan (1996) tavoin rakennemuutoksen ja kasvavien koulutusmahdollisuuksien sukupolveksi. Hiukan suppeammassa mielessä voidaan puhua myös ns. suuresta ikäluokasta (Karisto 2005). Tälle sukupolvelle ominaista on ollut kehitysoptimistinen lapsuus, vakavien sairauksien väheneminen, muutto maa- 


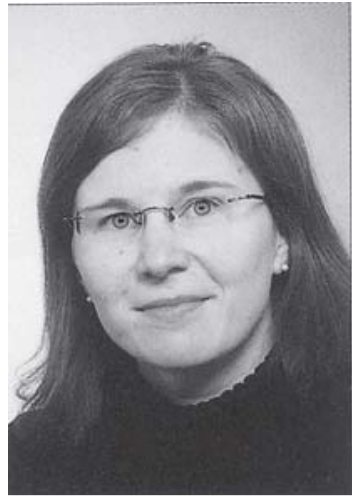

Nina Halttunen

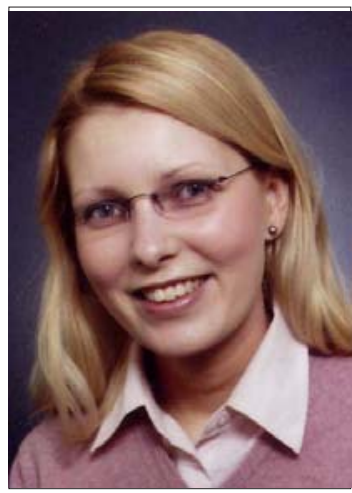

Marika Alho-Malmelin seudulta kaupunkeihin sekä yleinen turvallisuuden lisääntyminen. Koulunkäynti ja opiskelu ovat tämän sukupolven aikana saaneet uusia merkityksiä. Suuren ikäluokan sodasta selvinneet vanhemmat uskoivat koulutukseen ja halusivat lastensa kouluttautuvan. Koulutusajat pidentyivätkin merkityksellisesti tämän sukupolven ollessa kouluikäisiä ja koulutus ylipäätään on tarjonnut tälle sukupolvelle aikaisempaa merkittävästi enemmän mahdollisuuksia rakentaa elämänkulkua. Ammattiin kouluttautumisesta tuli keskeinen osa nuoruutta taloudellisen toimeentulon turvaamiseksi. Kouluttautumisesta tuli myös sosiaalisen nousun väline. Tässä ikäluokassa naisten asema kohosi ja naiset ovat ensimmäistä kertaa miehiä koulutetumpia. (Kauppila 1996, 89; Karisto 2005, 43; Roos 1988, 62; Virtanen 2005, 200; ks. myös Rinne \& Jauhiainen 2007.) Suurten ikäluokkien myötä myös yliopistokoulutus 1960-luvulla alkoi massoittua, kun yhä kasvavalle joukolle opiskeluikäisiä nuoria rakennettiin lisää kouluttautumismahdollisuuksia (ks. Ahola 1995, 79-85).

Kaikki suuresta ikäluokasta eivät tietenkään kasvaneista koulutusmahdollisuuksista huolimatta käyneet oppikoulua, kirjoittaneet ylioppilaaksi tai opiskelleet korkeakoulussa. Suuri joukko kävi vain kansakoulun ja jäi asumaan maaseudulle. Paikalliset koulutusmahdollisuudet ja kodin taloudelliset resurssit ovat olleet vahvasti määrittämässä sitä, millaisiksi yksilölliset koulutuspolut ovat muotoutuneet. 50 vuotta täyttäneet ovat käyneet koulunsa rinnakkaiskoulujärjestelmässä, jossa valinta kansalaiskoulun ja oppikoulun välillä viitoitti tulevaa tietä pitkälle eteenpäin. Valinnan tekivät vanhemmat, eikä ollut aina itsestään selvää, että kaikki olisivat toivoneet jälkikasvunsa kouluttautuvan mahdollisimman pitkälle. Nopea ammattiin valmistuminen saattoi olla paitsi vanhempien, myös oma toive. (Moore 2003, 73104.)

Koulutuksellisessa tasa-arvokeskustelussa on palattu yhä uudelleen kysymyksiin koulutuksen ulkopuolelle jäämisestä. On pohdittu, missä vaiheessa koulutusprosessia ja missä määrin eri ryhmät rajautuvat koulutuksen ulkopuolelle. Elinikäisestä oppimisesta puhuttaessa ei koulutukseen osallistumista nähdä enää oikeutena, vaan ennemminkin eri kansalaisryhmistä, kuten eri sukupolviryhmistä tulevien kykynä pysytellä oppimisen ja koulutuksen piirissä läpi elämänsä. Näin ollen elinikäistä oppimista voidaan kuvailla niin yhteiskunnan kuin yksilönkin selviytymisstrategiana, jossa muutoksen hallinta määrittää edellytykset pärjäämiselle. (Rinne \& Salmi 1998, 182, 141; Tuomisto 1997, 3.)

Aikuiskoulutuksesta puhutaan usein toisena mahdollisuutena, jolla voidaan tarkoittaa mahdollisuutta nuorena hankitun koulutuksen paikkaamiseen ja virhevalintojen korjaamiseen. Tästä näkökulmasta käsin yliopistokoulutus koulutuksen korkeimpana tikapuuna näyttäytyy tavoittelemisen arvoina heille, jotka eivät ole nuorempana voineet tätä tutkintoa suorittaa. (ks. Kivinen \& Rinne 1990, 141.) Toisen mahdollisuuden käyttäjinä voidaan nähdä ne opiskelijat, jotka eivät täytä yliopiston muodollisia pohjakoulutusvaatimuksia tai ovat muuten alioikeutetusta asemasta tulevia. Tiedetään kuitenkin, että nämä opiskelijat ovat yliopistoon tulevissa aikuisissa usein vähemmistönä. Huomattava osa aikuisena yliopistoon tulevista on jonkinlaisia "palaajia", jotka ovat aikaisemminkin hankkineet korkeakoulutusta, mutta tulevat takaisin koulutuksen pariin hankkiakseen lisää tai päivittääkseen kvalifikaatioitaan. Osa on myös eräänlaisia “lykkääjiä”, jotka syystä tai toisesta tulevat korkeakoulutukseen hieman tavallista myöhemmin. He eivät ole erityisesti alioikeutetuista asemista, mutta heillä on kenties tarvittavan pohjakoulutuksen hankkiminen kestänyt pidempään kuin tavallisesti tai he ovat tehneet elämässään siihen saakka jotain muuta. (Davies 1995, 287.)

Tarkastelemme artikkelissamme koulutusta elämänkulullisen näkökulman kautta ja näemme koulutuksen rakentavan elämänkulkua ja identiteettiä. Koulutus valtauttaa ihmisiä muuttamaan elämänkulkujaan. Se tarjoaa erilaisia resursseja identiteetin rakentamiseen ja vahvistamiseen sekä 
uusien alkujen löytämiseen. (Antikainen, Houtsonen, Kauppila, Komonen, Koski \& Käyhkö 2000.) Ihmisen kasvu ja kehitys kytkeytyvät aina johonkin historialliseen kontekstiin, aikaan, jossa vallitsevat tietyt rakenteet, arvot ja normit. Nämä reunaehdot ovat yhteisiä kokonaisille sukupolville, mutta lisäksi yksilölliset erot voivat ratkaisevasti vaikuttaa tietyssä ajassa tehtyihin valintoihin. Elämänkulun näkökulmasta ihmisen elämä kontekstoituu aina ympäröivään kulttuuriin, sen tarjoamiin mahdollisuuksiin ja rajoituksiin. (Marin 2001, 27-28.)

Tarkastelemme seuraavaksi empiiristen aineistojen avulla niitä aikuisia, jotka ovat hakeutuneet yliopisto-opiskelijoiksi 50-vuotiaina tai tätä vanhempana. Selvitämme ensin tilastoaineiston avulla, keitä ovat 50-vuotiaana tai tätä vanhempana yliopistoon pyrkineet ja päässeet. Aineisto kattaa 40 prosentin satunnaisotoksen kaikista Suomen yliopistoihin vuonna 2003 hakeneista henkilöistä. ${ }^{1}$ Se sisältää tietoja hakemisesta ja opiskelupaikan saannista sekä henkilöiden ja taustoista ja elämäntilanteista. Tätä tarkastelua varten olemme poimineet aineistosta kaikki 50 vuotta täyttäneet henkilöt (366 henkilöä), jotka ovat syntyneet vuonna 1953 tai tätä aiemmin. Koska 50 vuotta täyttäneet hakijat ovat heterogeeninen joukko, olemme myös jakaneet tutkimusjoukkoa aikaisempien koulutuspolkujen mukaan erilaisiksi ryhmiksi.

Valottaaksemme opiskelijaksi hakeutumisen problematiikkaa yksilötasolta käsin, kerromme lisäksi yhden yli 50-vuotiaana opiskelunsa aloittaneen tarinan. Pyrimme kuvaamaan hänen elämänkulkuaan ja hänen opiskelulleen antamia merkityksiä. Haastatteluaineisto $(\mathrm{N}=24)$, johon artikkelissa käyttämämme haastattelu kuuluu, on kerätty osana Turun yliopiston kasvatustieteiden laitoksella meneillään olevaa tutkimusta avoimen yliopiston väylän kautta tulleista aikuisopiskelijoista. Todellisuudessa kuva yli 50-vuotiaana opintonsa aloittaneesta on tietenkin paljon moninaisempi ja kertomukset elämänkulusta erilaisia. Kaikkien tutkimukseen osallistuneiden yli 50-vuotiaiden haastateltavien kertomuksille oli kuitenkin leimallista samantapainen suhtautuminen koulutukseen ja tapa nähdä koulutus osana omaan elämään eri aikakausina. Esiin nostamassamme kertomuksessa nämä piirteet ovat monipuolisesti ja voimakkaasti esillä, koska haastateltava itse pohtii laajasti ja jäsentyneesti tekemiään koulutusvalintoja.
50 vuotta täyttäneet hakijat tilastojen

valossa

Vuonna 2003 yliopistoihin haki yhteensä 925 vähintään 50-vuotiasta henkilöä. Heistä 240 eli hieman yli neljäsosa sai opiskelupaikan. Enimmäkseen 50 vuotta täyttäneet yliopistoon hakevat ja hyväksytyt olivat vielä työikäisiä. Suurin osa heistä oli alle 55-vuotiaita. Noin kuusi prosenttia oli 60 vuotta täyttäneitä ja pari prosenttia 65 vuotta täyttäneitä. Naiset ovat hieman nuorempia kuin miehet. Kun kaikkien keskimääräinen ikä on 53,6 vuotta, ovat naiset keskimäärin 53,1-vuotiaita ja miehet 54,8-vuotiaita.

50 vuotta täyttäneistä opiskelupaikan hakijoista suurin osa oli naisia. Miesten osuus hakeneista oli 30 prosenttia ja hyväksytyistä lähes 40 prosenttia, mikä vastaa yleisemminkin yliopistoopiskelijoiden sukupuolijakaumaa. Miehet ovat saaneet opiskelupaikan naisia useammin.

50 vuotta täyttäneiden hakijoiden painottuminen alle 60-vuotiaisiin näkyy myös, kun tarkastellaan heidän pääasiallista toimintaansa. Tieto pääasiallisesta toiminnasta on vuoden 2002 lopusta eli ajalta noin puoli vuotta ennen yliopistoon hakemista. Suurin osa on tuolloin kuulunut työlliseen työvoimaan. Työssä olevat ovat myös saaneet opiskelupaikan helpommin. Huomion kiinnittää suuri päätoimisten opiskelijoiden osuus verrattuna samanikäiseen väestöön. Monet tämän ikäisistä ovat siis opiskelleet myös juuri ennen yliopistoon hakemistaan. Sukupuolittain tarkasteltuna naiset ovat useammin työssä, kun taas miehet ovat suhteessa useammin päätoimisia opiskelijoita. Eläkeläiset puolestaan ovat hakijoiden joukossa selvästi aliedustettuina, ja heille myös opiskelupaikansaanti on ollut vaikeinta.

50 vuotta täyttäneistä yliopistoon pyrkijöistä suurin osa on pohjakoulutukseltaan ylioppilaita. Naiset ovat ylioppilaita useammin kuin miehet. Monet tästä joukosta ovat käyneet lukion vasta aikuisiässä (ks. myöh. ryhmittely tässä artikkelissa). Ei-ylioppilaat ovat saaneet opiskelupaikan jonkin verran useammin kuin ylioppilastutkinnon suorittaneet. Tämä on ehkä jossain mielessä yllättävää, jos ajatellaan, että enemmän koulutetuilla on paremmat sisäänpääsymahdollisuudet.

Aikuisena yliopisto-opintonsa aloittavat ovat useimmiten suorittaneet ammatillisen tutkinnon, usein jopa useita tutkintoja (Moore 2000, 92). 
Taulukko 1.50 vuotta täyttäneiden yliopistoon hakeneiden ja hyväksyttyjen taustatietoja

\begin{tabular}{|c|c|c|c|c|}
\hline & & $\begin{array}{l}\text { 50-59-vuotias } \\
\text { väestö* }\end{array}$ & Hakeneet & Hyväksytyt \\
\hline \multirow[t]{2}{*}{ Sukupuoli } & Nainen & & 69,7 & 62,2 \\
\hline & Mies & & 30,3 & 37,8 \\
\hline \multirow[t]{4}{*}{ Siviilisääty } & Naimaton & & 16,7 & 8,9 \\
\hline & Naimisissa & & 62,3 & 72,2 \\
\hline & Eronnut & & 18,3 & 16,7 \\
\hline & Leski & & 2,7 & 2,2 \\
\hline \multirow{5}{*}{$\begin{array}{l}\text { Pääasiallinen } \\
\text { toiminta }\end{array}$} & Työssä & 73,6 & 73,2 & 82,2 \\
\hline & Työtön & 6,0 & 8,2 & 7,8 \\
\hline & Opiskelija & 0,3 & 9,8 & 7,8 \\
\hline & Eläkeläinen (ml. tyött.eläk.) & 13,1 & 6,0 & 2,2 \\
\hline & Muu/tuntematon & 7,1 & 2,7 & - \\
\hline \multirow[t]{2}{*}{ Pohjakoulutus } & Yo-tutkinto & & 71,3 & 68,9 \\
\hline & Ei yo-tutkintoa & & 28,7 & 31,1 \\
\hline \multirow{6}{*}{$\begin{array}{l}\text { Korkeimman } \\
\text { suoritetun } \\
\text { tutkinnon aste }\end{array}$} & Ei perusasteen jälk. koulutus & 33,7 & - & - \\
\hline & Keskiaste & 38,0 & 21,1 & 10,2 \\
\hline & Opistoaste & 14,9 & 38,5 & 25,0 \\
\hline & Alempi korkeakoulututkinto & 6,2 & 28,5 & 45,5 \\
\hline & Ylempi korkeakoulututkinto & 6,2 & 10,5 & 15,9 \\
\hline & Tutkijakoulutus & 0,9 & 1,4 & 3,4 \\
\hline \multirow{10}{*}{$\begin{array}{l}\text { Korkeimman } \\
\text { suoritetun } \\
\text { koulutuksen ala }\end{array}$} & Yleissivistävä & & 10,5 & 3,4 \\
\hline & Kasvatustiet. ja opett.koul. & & 7,5 & 15,9 \\
\hline & Humanistinen ja taidealan & & 8,6 & 12,5 \\
\hline & Kaupall. ja yhteiskuntatiet. & & 32,1 & 31,8 \\
\hline & Luonnontieteellinen & & 2,5 & 4,5 \\
\hline & Tekniikan & & 10,2 & 12,5 \\
\hline & Maa- ja metsätalousalan & & 1,7 & 1,1 \\
\hline & Terveys- ja sosiaalialan & & 23,0 & 13,6 \\
\hline & Palvelualojen & & 3,6 & 4,5 \\
\hline & Muu/tuntematon & & 0,3 & 0,0 \\
\hline \multicolumn{5}{|c|}{ Sosioekonominen } \\
\hline \multicolumn{2}{|c|}{ Maatalousyrittäjä } & & 0,8 & 2,2 \\
\hline \multirow[t]{7}{*}{ asema } & Muu yrittäjä & & 3,3 & 3,4 \\
\hline & Ylempi toimihenkilö & & 39,0 & 56,2 \\
\hline & Alempi toimihenkilö & & 30,1 & 23,6 \\
\hline & Työntekijä & & 3,6 & 2,2 \\
\hline & Opiskelija & & 7,0 & 3,4 \\
\hline & Eläkeläinen & & 4,7 & 0,0 \\
\hline & Muu/tuntematon & & 10,4 & 9,0 \\
\hline \multirow[t]{6}{*}{ Tulot } & Ei tuloja & & 0,5 & 0,0 \\
\hline & $1-84499$ & & 10,7 & 3,3 \\
\hline & $8500-16499$ & & 11,5 & 4,4 \\
\hline & $16500-24999$ & & 20,8 & 23,3 \\
\hline & $25000-34999$ & & 33,1 & 32,3 \\
\hline & $35000-$ & & 23,5 & 36,7 \\
\hline
\end{tabular}


Aineistomme ei anna mahdollisuutta tarkastella eri tutkintoja, vaan ainoastaan korkeinta suoritettua tutkintoa. Hakeneilla ylin hankittu tutkinto oli useimmiten opistotasoinen, mutta hyväksytyksi tulleilla yleisin koulutus oli alempi korkeakoulututkinto. Mitä korkeampi tutkinto hakijalla on, sitä todennäköisemmin hän on saanut opiskelupaikan. Ylemmän korkeakoulututkinnon oli hankkinut yhteensä 12 prosenttia hakeneista ja miltei viidesosa hyväksytyistä. Naisilla opistotason tutkinto on selvästi yleisempi kuin miehillä. Miehillä taas on selvästi naisia useammin ylempi korkeakoulututkinto. Kaiken kaikkiaan yliopistoon hakeneet 50 vuotta täyttäneet ovat selvästi suorittaneet useammin korkeampia tutkintoja kuin samanikäinen väestö keskimäärin. Kaikilla hakeneilla on jokin perusasteen jälkeen hankittu tutkinto.

Noin 40 prosenttia hakeneista oli suorittanut korkeimman tutkintonsa 1970-luvulla. Noin neljäsosa oli opiskellut 1980-luvulla ja niin ikään noin neljäsosa 1990-luvulla. 2000-luvulla oli korkeimman tutkintonsa suorittanut noin joka kymmenes. 50 vuotta täyttäneenä opiskelupaikkaa yliopistosta hakevia voidaan siis luonnehtia elinikäisiksi oppijoiksi. Suurin osa heistä on hankkinut koulutusta nuoruusvuosiensa jälkeen ja moni on suorittanut aikuisiällä myös tutkintoja.

Yleisimmin 50 vuotta täyttäneet olivat hankkineet koulutuksensa kaupalliselta ja yhteiskuntatieteelliseltä alalta. Jos sukupuolia tarkastellaan erikseen, on naisten yleisin koulutusala kaupallinen ja yhteiskuntatieteellinen (37 \%) ja toiseksi yleisin terveys- ja sosiaaliala (30\%). Miehillä yleisin koulutusala on tekniikka (30 \%) ja toiseksi yleisin kaupallinen ja yhteiskuntatieteellinen (22 $\%)$. On myös huomattava, että noin joka kymmenennellä 50 vuotta täyttäneellä hakijalla korkeimman tutkinnon ala on yleissivistävä eli heillä ei ole ylioppilastutkinnon lisäksi muita tutkintoja.

Hakijoiden aiempi koulutus näkyy jonkin verran siinä, mihin aloille he ovat pyrkimässä ja mitä reittiä pitkin he ovat hakemassa opiskelupaikkaa. Etenkin naiset hakevat usein opiskelemaan kasvatus- ja yhteiskuntatieteitä. Myös lääketieteellinen tiedekunta (joissa useimmiten hoitotiede) on yleinen hakukohde. Miehillä yleisimmät tiedekunnat ovat niin ikään kasvatustieteellinen ja yhteiskuntatieteellinen, mutta selvästi yliedustettuina ovat teologinen, oikeustieteellinen ja teknillinen tiedekunta.

50 vuotta täyttäneistä hakijoista suurin osa tulee opiskelijaksi erilaisten erillisvalintojen kautta. Muunto- ja maisterikoulutukset on tarkoitettu ensisijaisesti työelämässä toimiville. Tämän reitin käyttö edellyttää aiempia opintoja, ja nämä hakijat ovatkin selvästi muita useammin suorittaneet alemman korkeakoulututkinnon. Aikuiset opiskelevat paljon myös avoimessa yliopistossa ja hakeutuvat tutkinto-opiskelijoiksi sitä kautta. Avoimen yliopiston väylä on vanhemmissa ikäryhmissä melko tärkeä sisääntulokanava. Se on reitti, jota pitkin eteneminen ei ole kiinni aiemmista tutkinnoista ja väylä erottuukin muista reiteistä siinä, että melkein puolet tätä polkua käyttäneistä yli 50-vuotiaista on ei-ylioppilaita. Käytännössä tämä väylä kuitenkin on kapea, sillä avoimen yliopiston opintojen tarjonta on useilla aloilla suppeaa ja keskittynyt vain alempiin opintoihin (Kess, Hulkko, Jussila, Kallio, Larsen, Pohjolainen \& Seppälä 2002, 54-55; ks. myös Rinne, Jauhiainen, Tuomisto, Alho-Malmelin, Halttunen, \& Lehtonen 2003; Piesanen 2005; Halttunen \& Nori 2006.)

Elämäntilannetta ja asemaa voidaan tarkastella myös sosioekonomisen aseman ja ammatin avulla. Tiedot näistä ovat aineistossa vuodelta 2000 eli ajalta kolme vuotta ennen yliopistoon pyrkimistä. Suurin osa hakeneista on tuolloin ollut toimihenkilöasemassa. Ylempiä toimihenkilöitä oli yli kolmasosa ja alempia hieman alle kolmasosa hakeneista. Yksittäisistä ammateista sairaanhoitajia oli hakeneiden joukossa kaikkein eniten, noin joka kymmenes. Hyväksytyistä taas joka kymmenes oli ammatiltaan opettajana ammattikorkeakoulussa tai ammatillisessa oppilaitoksessa. 50 vuotta täyttäneet hakijat olivat keski- tai suurituloisia. Korkeat tulot ovat myös yhteydessä opiskelupaikan saamiseen. Reilusti yli kolmasosa hyväksytyksi tulleista ansaitsi vähintään 35000 euroa vuodessa.

\section{Erilaisia koulutuspolkuja}

50 vuotta täyttäneiden joukkoon mahtuu monenlaisia elämäntilanteita, koulutus- ja elämänpolkuja. Tilastoaineiston avulla ryhmittelimme tämän joukon aiemman koulutuspolun mukaan neljään eri ryhmään: toisen tutkinnon suorittajiin, toisen mahdollisuuden käyttäjiin, myöhään aloittaneisiin ja lisäkouluttautujiin. Tämä ryhmittely on saanut vaikutteita mm. Daviesin (1995) sekä Mooren (2000) ryhmittelyistä.

Toisen tutkinnon suorittajiksi määritimme ne hakijat, joilla on jo aiemmin suoritettuna ylempi 
korkeakoulututkinto. He ovat eräänlaisia yliopistokoulutuksen suurkuluttajia. Toisen tutkinnon suorittajista melkein neljäsosa on ei-ylioppilaita ja he ovat siis aiemmin hakeutuneet yliopistoon epätyypillistä reittiä pitkin. Kaikilla on kuitenkin tällä hetkellä yliopistotutkinto ja jopa 12 prosentilla hakeneista on myös tutkijakoulutus. Yleisimmin koulutus on hankittu kaupalliselta ja yhteiskuntatieteelliseltä alalta. Noin joka kuudes on suorittanut korkeimman tutkintonsa 1970-luvulla, puolet 1980-luvulla ja 13 prosenttia 1990-luvulla. 2000luvulla korkeimman tutkintonsa on suorittanut seitsemän prosenttia hakeneista. Huomattava osuus, miltei viidesosa, oli hakiessaan päätoimisia opiskelijoita

Toisen mahdollisuuden käyttäjiksi määritimme ne hakijat, joilla ei ole ylioppilastutkintoa. Kaikilla on kuitenkin jokin ammatillinen tutkinto. 42 prosenttia on hankkinut opistotasoisen koulutuksen ja 38 prosenttia alemman korkeakoulututkinnon. Keskiasteen tutkinto on viidesosalla. Yleisimmin tutkinto on hankittu kaupalliselta/yhteiskuntatieteelliseltä alalta tai terveys- ja sosiaalialalta. Reilut 40 prosenttia on hankkinut korkeimman tutkintonsa 1990-luvulla. Melkein puolet on opiskellut tutkintonsa tätä ennen ja reilu kymmenesosa vasta 2000-luvulla. Vajaat seitsemän prosenttia opiskeli päätoimisesti hakiessaan opiskelupaikkaa.

Myöhään aloittaneiksi määritimme ne hakijat, joilla on ylioppilastutkinto, mutta ei sen jälkeen hankittua ammatillista tutkintoa. Tähän ryhmään kuuluvat ovat voineet hankkia ammatillista osaamista kuitenkin esim. erilaisten kurssien kautta. Ylioppilastutkinnon on 1970-luvulla (eli nuorena) suorittanut vain vajaa kolmasosa. Suurin osa tähän ryhmään kuuluvista on siis hankkinut ylioppilastutkintonsa vasta aikuisiällä: noin viidesosa 1980-luvulla, reilu neljäsosa 1990-luvulla ja reilu viidesosa 2000-luvulla. Tähän ryhmään kuuluvilla onkin muihin ryhmiin verrattuna tuoreimmat tutkinnot. Myös hakuhetkellä päätoimisesti opiskelevien osuus oli suurin tässä ryhmässä, miltei neljäsosa.

Lisäkouluttautujiksi määritimme ne hakijat, joilla oli ylioppilastutkinto ja jotka ovat hankkineet sen lisäksi ammatillisen tutkinnon. Reilulla puolella on opistoasteen tutkinto, reilulla kolmasosalla alempi korkeakoulututkinto ja joka kymmenennellä keskiasteen ammatillinen tutkinto. Myös tähän ryhmään kuuluvilla tutkinto on yleisimmin kaupalliselta/yhteiskuntatieteelliseltä alalta (39 \%:lla), mutta myös terveys- ja sosiaali- alan tutkintoja (27\%) on jonkin verran. Puolet on hankkinut tutkintonsa 1970-luvulla tai sitä ennen. 1990-luvulla on tutkinnon opiskellut noin neljäsosa ja 2000-luvulla vajaa kymmenesosa. Tähän ryhmään kuuluvilla onkin kaikkein "vanhimmat” tutkinnot muihin ryhmiin verrattuna. Hakuhetkellä opiskelevien osuus oli myös tässä ryhmässä pienin, noin kuusi prosenttia.

Ryhmät eroavat toisistaan myös muuten kuin aiemman koulutuksensa suhteen. Toisen tutkinnon suorittajat on ainut ryhmä, jossa enemmistö, 58 prosenttia, on miehiä. Lisäkouluttautujat puolestaan on naisvaltaisin ryhmä, sillä vain viidesosa tähän ryhmään lukeutuvista on miehiä. Lisäkouluttautujat on myös iältään nuorin ryhmä, ja tässä ryhmässä lähes kolmasosalla on (vielä kotona asuvia) lapsia.

Kaikissa ryhmissä enemmistö on työssäkäyviä. Eniten työssäkäyviä on lisäkouluttautujien ryhmässä ja vähiten myöhään aloittaneiden ryhmässä. Ryhmät eroavat toisistaan siinä, millaisissa ammatillisissa asemissa niihin kuuluvat ovat. Toisen tutkinnon suorittajat ovat yleensä ylempiä toimihenkilöitä ja he työskentelevät useimmiten erilaisissa asiantuntija- ja johtotehtävissä eli ammateissa, joiden yleisesti ottaen katsotaan edellyttävän korkeakoulututkintoa. Vakiintunut ja korkea asema työelämässä näkyy myös tämän ryhmän tuloissa, sillä tämä on selvästi kaikkein suurituloisin ryhmä.

Seuraavaksi "parhaimmin” työelämässä ovat asemoituneet lisäkouluttautujat ja toisen mahdollisuuden käyttäjät. Kummassakin ryhmässä on paljon sairaanhoitajia sekä erilaisissa opetus- ja sosiaalialan asiantuntijatehtävissä toimivia. Myöhään aloittaneet on kaikkein "matalimman" statuksen omaavin ryhmä. Ylempien toimihenkilöiden osuudet ovat tässä ryhmässä pienimmät. Yksittäisistä ammateista erottuu sihteeri, joita on peräti kolmasosa tähän ryhmään kuuluvista. Myös tulot ovat tähän ryhmään kuuluvilla selvästi muita ryhmiä pienemmät.

Suurin ryhmä 50 vuotta täyttäneiden yliopistoon hakeutuneiden joukossa ovat lisäkouluttautujat, joita on noin puolet hakeneista ja hyväksytyistä. Pienin ryhmä puolestaan on myöhään aloittaneet, joita on kymmenesosa hakeneista ja vain muutama prosentti hyväksytyistä. Mielenkiintoista on, että kaikkein parhaiten koulutettujen ryhmän, toisen tutkinnon suorittajien on kaikkein helpointa saada opiskelupaikka. Nämä opiskelijat vertautuvat Daviesin (1995) ryhmittelyn 'palaajiin'. Sekä 
Taulukko 2.50 vuotta täyttäneiden hakijoiden ryhmittely

Toisen tutkinnon suorittajat

Toisen mahdollisuuden käyttäjät

Myöhään aloittaneet

Lisäkouluttautujat

Yhteensä

lisäkouluttautujat että toisen mahdollisuuden käyttäjät puolestaan ovat eräänlaisia korkeakoulutukseen tulon 'lykkääjiä'. Kaikkein vaikeinta opiskelupaikan saanti on myöhään aloittaneille. Nämä aidoimmin Daviesin ryhmittelyn 'toisen mahdollisuuden käyttäjiin' vertautuvat aikuiset eivät näytä menestyvän opiskelupaikoista käytävässä kilpailussa. Yliopistojen valikointimekanismit siis kohtelevat erilaisen taustan omaavia eri tavoin.

\section{"Et sit jos on valmis TUTKINTO jostain, niin se on ihan toinen juttu"}

Haastateltavamme on yli 50-vuotias nainen, joka on aikaisemmalta koulutukseltaan sairaanhoitaja. Hän on hakeutunut opiskelemaan kasvatustiedettä avoimen yliopiston väylää pitkin. Samanaikaisesti yliopisto-opintojen kanssa hän opiskelee myös toisessa koulutuksessa. Haastateltava on naimisissa ja hänellä on aikuisiän kynnyksellä olevia lapsia. Työn, perheen ja opiskelun yhteen sovittaminen onkin aikuisille opiskelijoille usein arkipäivää (ks. Moore 2003, 128-135).

Edellä esitetyssä tilastoaineiston pohjalta tehdyssä jaottelussa haastateltavamme sijoittuu suurimpaan ryhmään eli lisäkouluttautujien joukkoon. Myös sukupuoleltaan ja ammatiltaan hän on tyypillinen yli 50-vuotias hakija. Hän on nuorena kouluttautunut ylioppilaaksi ja tämän jälkeen hankkinut ammatillisen koulutuksen sairaanhoitoopistossa. Haastateltava kuvaa hakeutumista ammatilliseen koulutukseen jonkinlaisena ajautumisena: "Et ei mul ollu mitään erityisiä intressejä sinne mennä.” Hän olisi halunnut ensisijaisesti opiskelemaan yliopistoon, mutta pääsykokeisiin valmistautuminen ei houkutellut. Opiskelupaikan valinta ei kuitenkaan kaduttanut haastateltavaa, ja sairaanhoito-opistoon pääsyään hän kuvaa "elämänsä onnenkantamoiseksi". Mielessä kyti ajatus, että yliopistoon voisi hakea opiskelemaan myöhemmin, mutta vähitellen opintohalut laantuivat. "Et tarttis rahaakin saada, ni ta...."
Hakeneet

11,9

Hyväksytyt

24,9

19,3

10,5

27,3

52,6

100

50,0

100

jäi se opiskelu.”

Suurille ikäluokille koulutus on näyttäytynyt pääasiassa välineenä, jonka avulla saavutetaan vakaa työmarkkina-asema. Leimallista tälle suurten ikäluokkien sukupolvelle oli niinikään ”helppo työllistyminen” taloudellisen kasvun vuosikymmeninä, 1960- ja 1970-luvuilla. (Kauppila 1996, 80 81.) Myös haastateltavamme kertoi valmistumisensa jälkeen töitä olleen runsaasti tarjolla. ”Et tilanne oli semmonen aika kiva siinä mielessä, et voi vapaasti valita mihin kaupunkiin ja mitä työtä tekee, ni aina toivotettiin tervetulleeks.”

Myös perheen perustaminen näyttäytyi haastateltavallemme ongelmattomana. Tarkasteltavan sukupolven naisille perhe, lastenhoito ja miehen intressit menivät usein omien koulutus- ja työurasuunnitelmien edelle. Naiset eivät kuitenkaan nähneet sitä "uhrautumisena” vaan hyvin luonnollisena ja neutraalina elämänkokemuksena. (Kauppila 1996, 86.) "Et kun mä tapasin mieheni ja mentiin naimisiin ja aloin silloin odottaa las-

Laman myötä myös sairaanhoitajien työtilanne huonontui. "Hiukan pieni paniikki sit tuli tietenkin siitä. — ni sillon mä menin itseasias avoimeen yliopistoon opiskelemaan." Avoimen yliopiston opintojensa myötä hän palasi nuoruutensa kiinnostuksen pariin. Opiskelu merkitsi hänelle tietynlaista varmistelua työelämän kannalta, mutta samalla hän painotti sitä, että opiskelu oli harrastus ja eräänlaista irtiottoa arkisesta kotielämästä. ’En mä ikinä ajatellut, että siit olis mulle mittään konkreettista hyötyy."

Haastateltavamme on opiskellut vuosien varrella lisää omaan ammattiinsa liittyviä opintoja sekä avoimen yliopiston opintoja. Hän on edennyt myös urallaan ja hänen työtehtävänsä ovat muuttuneet kokemuksen ja lisäkoulutuksen myötä vaativammiksi. Kouluttautumisen ja työelämän suhteen pidennetyn nuoruuden eläminen ja oman paikan etsiminen ovat olleet mahdollisia suurten ikäluokkien sukupolvelle uudella tavalla. Ikäluokalla on ollut mahdollisuus hankkia lisäkoulutusta 
ja kokeilla erilaisia työtehtäviä. Tavallista onkin, että suuriin ikäluokkiin kuuluvilla on ollut työurallaan keskimäärin kolme ammattia (Savioja ym. 2000, 68).

Haastateltavamme mietti edelleenkin tulevaisuuttaan työnsä suhteen: "Ja sit viime keväänä mä aloin miettimään tätä tulevaisuuttani, et mitä se sit tarkottaa.” Opiskelu näyttäytyi haastateltavallemme jälleen ratkaisuna tilanteeseen. Hän haki samanaikaisesti kahteen koulutuspaikkaan ja pääsi molempiin. Hän opiskelee kahdessa eri paikassa, kahdella eri paikkakunnalla, mikä tekee elämästä kiireistä. Nykyinen työ yhtäältä mahdollistaa sen, että voi joustavasti järjestellä työaikojaan, mutta toisaalta sovitut työt on tärkeitä hoitaa. "Et työt on mun ensisijainen juttu. Nää on toissijaisia nää opiskelut."

Haastateltava painottaa sitä, ettei enää aio vaihtaa työpaikkaa. Uudelleenkouluttautuminen tai ammatin vaihto eivät enää ennen eläkeikää usein näyttäydykään kovin mielekkäinä, mutta toisaalta monet kaipaavat uutta sisältöä nykyiseen työhönsä (Savioja ym. 2000, 68). Haastateltavamme kertoo käyvänsä jonkin verran alansa erilaisissa kansainvälisissä koulutuksissa. Valtaosalla kollegoista on akateeminen loppututkinto ja myös tieteellisiä meriittejä. Näissä ammattikuntansa yhteisissä tapaamisissa haastateltava kertoo tuntevansa olonsa joskus "aivan toisen luokan kansalaiseksi, kun ei ole mitään julkaisuja, mitä vois sanoa.” Tulevaisuuteen liittyvänä haaveenaan hän tuokin esille sen, että voisi ehkä suorittaa myös jatko-opintoja ja tehdä jonkinlaista tutkimusta:

”Et kyl mä tiedän, ettei tästä mulle työelämään ole mitään konkreettista hyötyä tästä opiskelusta... Ni mä nään sen semmosena mahdollisuutena, et mä voin ajatella, et jos mä teen jotain tutkimusta. Innostun vaikka semmosesta.”

Puheessa toistuu monesti, ettei haastateltava koe opiskelusta olevan itselleen mitään konkreettista hyötyä. Jokin häntä opintoihin kuitenkin vetää; hän kuvaa itse sitä jonkinlaisena tarpeena saada asioita valmiiksi:

”... et mun täytyy saada se appro valmiiksi. Et joku tutkinto. Kun esimerkiksi näitä opintoja, mitä mä olen suorittanut. Niitä ei oikeesti noteerattu yhtään missään. Kun ei se kerta ole tutkinto, niin ne menee niin kun tavallaan hukkaan. Et työpaikkahaastattelussa - et jos siellä rupesi luettelemaan jollekin, joka ei esimerkiksi ole korkeakoulussa itse opiskellut, että sit mulla on se ja se appro, ni ei semmonen ketään kiinnosta. Et sitte jos on valmis TUTKINTO jostain, niin se on ihan toinen juttu. Et jokanen ymmärtää et ahaa se on sen alan tutkinto.”

Haastateltavan tarina näyttäytyy eräänlaisena päättymättömänä sarjana aina uusia ja uusia koulutuksia, joille tyypillistä on eräänlainen positiivinen ajautuminen. Avoimen yliopiston opinnot rohkaisivat jatkamaan opintoja yhä lisää ja tätä kautta myös tutkinto-opinnot yliopistossa tulivat lopulta ajankohtaisiksi. Tämä onkin eräällä tavalla naisille tyypillinen tapa kuvata opiskelijaksi tuloaan, ei niinkään suunniteltuina valintoina, vaan ajautumisena (Moore 2003, 96).

Haastateltavallemme koulutukseen osallistuminen on näyttäytynyt siinä määrin mahdollisuutena, että hän on ammentanut useita kertoja opinnoiltaan elämänkulkunsa varrella itselleen voimavaroja. Haastateltavamme on rakentanut elämäänsä koulutuksen avulla. Opiskelu ensin avoimessa yliopistossa ja myöhemmin yliopistossa eivät kuitenkaan ole puutteellisen koulutuksen paikkausta. Haastateltavamme on tehnyt menestyksekkään ja mielenkiintoisen työuran ilman korkeakoulututkintoa, joka näyttäytyykin ”jälkikäteen suoritettuna” vain pelkkänä tutkintotodistuksena.

\section{Lopuksi}

50 vuotta täyttäneet ovat uusien yliopisto-opiskelijoiden joukossa hyvin pieni vähemmistönsä. Suomalaisen yliopistojärjestelmän jonkinlaisesta avoimuudesta kuitenkin kertoo, että vielä keskiiässä on mahdollista aloittaa tutkintoon tähtäävät opinnot. 50-vuotiaana tai tätä vanhempana yliopistoon hakevat ovat myös varsin heterogeeninen joukko, vaikka he taustoiltaan ovatkin selvästi keskimääräistä “parempiosaisia”. Samanikäiseen väestöön verrattuna yliopistoon hakevat ovat selvästi korkeammin koulutettuja ja varsin usein ylemmässä toimihenkilöasemassa. Voidaan myös sanoa, että opiskelu ja oppiminen ovat näiden aikuisten elämässä vahvasti läsnä. Tarkastelemastamme joukosta hyvin monet ovat suorittaneet tutkintoja aikuisella iällä ja huomattava osuus heistä on ollut päätoimeltaan opiskelijoita hakiessaan opiskelupaikkaa yliopistosta.

Jaoimme tutkimamme joukon neljään eri ryhmään. Näistä ryhmistä toisen tutkinnon suorittajat ovat selvästi hyväosaisten joukko. Heille toinen yliopistotutkinto ei edusta ylempää tai korkeampaa saavutusta kuin mihin he ovat aiemminkaan 
yltäneet. Yliopistotutkinnon suorittaminen näyttäytyy näille aikuisille ehkä arkisenakin asiana, lisäpätevöitymisenä tai itsensä kehittämisenä, miksei myös alanvaihtona ja siten uutena aluevaltauksena.

Toisen mahdollisuuden käyttäjiksi nimetty ryhmä voidaan ajatella olevan tietyssä mielessä huono-osaisin näistä ryhmistä, sillä he eivät ole suorittaneet ylioppilastutkintoa eivätkä siten täytä yliopiston perinteisiä sisäänpääsyvaatimuksia. Ylioppilastutkinnon puuttuminen ei kuitenkaan näytä aineiston valossa olleen näille aikuisille ongelma, onhan mm. toisen tutkinnon suorittajissa paljon myös heitä, joilla ei ole ylioppilastutkintoa. Työelämässä toisen mahdollisuuden käyttäjät näyttävät olevan pitkälti samantyyppisissä asemissa kuin lisäkouluttautujienkin ryhmään kuuluvat.

Jos ajatellaan eri ryhmien taustoja ja elämäntilanteita, näyttäytyvät myöhään aloittaneet ryhmänä, jolla olisi ehkä kaikkein eniten "kiinniotettavaa” suhteessa muihin ryhmiin. He ovat työelämässä kaikkein matalimmissa asemissa. Ehkä juuri tämän ryhmän kohdalla voitaisiin puhua toisesta mahdollisuudesta siinä mielessä, että heiltä on jäänyt ammatillinen tutkinto aiemmin hankkimatta. Suurin osa tähän ryhmään kuuluvista on hankkinut myös ylioppilastutkintonsa vasta aikuisiällä ja ovat siten kenties aidoimmin toisen mahdollisuuden jäljillä. Opiskelijuus luonnehtii tätä ryhmää eniten, sillä hakuhetkelläkin jopa neljäsosa on opiskelijoita päätoimeltaan.

Kaikkein suurin ryhmä ovat lisäkouluttautujat, jotka siis ovat elämänsä aikana hankkineet koulutusta myös tutkintoina. Toisen mahdollisuuden käyttäjien ja lisäkouluttautujien ryhmät muistuttavat huomattavan paljon toisiaan. Näihin ryhmiin lukeutuvat ovat samantapaisissa asemissa työelämässä ja heillä on myös hyvin samantyyppinen ammatillinen koulutus. Erona näiden ryhmien välillä siis on, että toisen mahdollisuuden käyttäjät ovat päätyneet asemiinsa ja koulutusreiteilleen ilman ylioppilastutkintoa, lisäkouluttautujilla ylioppilastutkinto taas on. Heissä on myös selvästi vähemmän päätoimisia opiskelijoita kuin kahdessa muussa ryhmässä ja heillä on lisäksi kulunut eniten aikaa aiempien tutkintojen suorittamisesta. Tietysti nämä aikuiset ovat saattaneet hyvinkin aktiivisesti osallistua erilaisiin aikuiskoulutuksen muotoihin, jotka eivät johda tutkintoihin, kuten avoimeen yliopistoopetukseen.
Tapauskuvauksessa tarkastelemamme opiskelija edustaa taustoiltaan selvästi tämän ikäisten opiskelijoiden enemmistöä. Ryhmittelyssämme hän sijoittuu lisäkouluttautujiin. Yksilöllisissä elämäntarinoissa on tietysti aina niin paljon vaihtelua, ettemme tämän yhden tapauksen perusteella voi vetää yleisiä johtopäätöksiä keski-ikäisten yliopisto-opiskelijoiden motiiveista tai suunnitelmista. Voimme kuitenkin valottaa niitä mahdollisia merkityksiä, joita opiskelulla voi tämän ikäisille olla.

Tilastoaineiston perusteella voidaan sanoa, että opiskelijuus luonnehtii näiden aikuisten elämää jo ennen tutkinto-opiskelun aloittamista. Tapauskuvauksessa tämä tulee hyvin esille haastateltavamme opintoina avoimessa yliopistossa ja yhä kiihtyvänä haluna kehittää itseään erilaisissa koulutuksissa. Voimme myös pohtia, millaisena toisena mahdollisuutena tutkinto-opiskelu haastattelun aikuiselle opiskelijalle näyttäytyy. Nuoruudessa hankittu sairaanhoitajan koulutus oli aikanaan tuntunut oikealta ratkaisulta ja tuntui siltä edelleen. Ehkä nyt opiskeltava tutkinto ei näyttäydykään aiemmin hankitun paikkaamisena ja jonkin sellaisen hankkimisena, josta olisi aiemmin jääty paitsi. Kyse on ennemminkin tien kulkemisesta edelleen eteenpäin ja erilaisten mahdollisuuksien käyttöön ottamisesta sitä mukaa, kun niitä avautuu. (ks. Moore 2000, 138-139.)

Tyypillisesti 50 vuotta täyttäneet yliopistoon pyrkijät ovat melko kouluttautuneita, elinikäisiä oppijoita, jotka ovat hankkineet ammatillista osaamista niin kokemuksen kuin koulutuksenkin kautta. He ovat saavuttaneet hyvän aseman työelämässä ja tarvitsevat nyt lisää muodollista pätevyyttä tai yleensä tavoitteita ja haasteita itselleen. Joillekin opiskelu saattaa merkitä myös suunnanvaihdosta elämässä, alanvaihtoa, unelman toteuttamista "viime hetkellä”, kun siihen vielä on mahdollisuus. Tai kuten haastateltavallemmekin, kyse saattaa olla eräänlaisesta "henkisestä" pätevöitymisestä, näyttämisestä itselleen ja ehkä muillekin, asioiden valmiiksi saattamisesta. Yliopistokoulutus näyttäytyy täten jonkinlaisena johdonmukaisena seurauksena aiemmin kuljetusta koulutuspolusta.

\section{Lähteet}

Ahola, S. (1995). Eliitin yliopistosta massojen korkeakolutukseen. Korkeakoulutuksen muuttuvat asema yhteiskunnallisen vali- 
koinnin järjestelmänä. Koulutussosiologian tutkimuskeskuksen raportteja 30. Turun yliopisto.

Antikainen, A., Houtsonen, J., Kauppila, J., Komonen, K., Koski, L. \& Käyhkö, M. (2000). Koulutuksen merkitys identiteetin ja kulttuurin rakentajana. Teoksessa R. Raivola (toim.) Vaikuttavuutta koulutukseen. Suomen akatemian koulutuksen vaikuttavuusohjelman tutkimuksia. Suomen Akatemian julkaisuja 2/00, 231-253.

Davies, P. (1995). Themes and Trends. In P. Davies. (ed.) Adults in Higher Education. International Perspectives in Access and Participation. London: Jessica Kingsley Publishers.

Halttunen, N. \& Nori, H. (2006). Avoimen yliopiston väylä reittinä tutkinto-opiskeluun. Teoksessa M-L. Julkunen (toim.) Tutkimuksia yhtenäistyvistä ja erilaistuvista oppimisen ja koulutuksen poluista. Joensuun yliopiston Kasvatustieteiden tiedekunnan tutkimuksia 98. Joensuun yliopistopaino. 151-172.

Houtsonen, J. (1996). Koulutusidentiteetin kulttuurisen rakentumisen ainekset: identiteettien tyypittelyt ja elämänkerralliset teemat. Teoksessa Antikainen, A. \& Huotelin, H. (toim.) Oppiminen ja elämänhistoria. Aikuiskasvatuksen 37. vuosikirja. Kansanvalistusseura ja Aikuiskasvatuksen Tutkimusseura. 199-261.

Jyrkämä, J. (2001). Aika tutkimuksessa ja elämänkulussa. Teoksessa A. Sankari \& J. Jyrkämä (toim.). Lapsuudesta vanhuuteen. Iän sosiologia. Tampere: Vastapaino. 117-157.

Jyrkämä, J. (2005). Syntynyt 1947, kuollut...? Teoksessa Karisto, A, (toim.). Suuret ikäluokat. Tampere: Vastapaino. 347-363.

Karisto A, (2005). Suuret ikäluokat kuvastimessa. Teoksessa Karisto, A, (toim.). Suuret ikäluokat. Vastapaino, Tampere. 17-58.

Kauppila, J. (1996). Koulutus elämänkulun rakentajana. Teoksessa A. Antikainen, A. \& H. Huotelin (toim.), Oppiminen ja elämänhistoria. Aikuiskasvatuksen vuosikirja. Kansanvalistusseura ja Aikuiskasvatuksen Tutkimusseura. 45-108.

Kess, P., Hulkko, K., Jussila, M., Kallio, U., Larsen, S., Pohjolainen, T. \& Seppälä, K. (2002). Suomen avoin yliopisto. Avoimen yliopistoopetuksen arviointiraportti. Korkeakoulujen arviointineuvoston julkaisuja 6. Helsinki: Edi- ta.

Kivinen, O. \& Rinne R. (1990). Aikuiskoulutuksen näköalat ja korkeakoulujen täydennyskoulutus. Teoksessa O. Kivinen \& R. Rinne (toim.) Korkeakoulut aikuiskoulutusmarkkinoilla. Koulutussosiologian tutkimuskeskuksen tutkimusraportteja 4. Turun yliopisto.

Kivinen, O. \& Rinne, R. (1995). Koulutuksen periytyvyys. Nuorten koulutus ja tasa-arvo Suomessa. Koulutus 1995: 4. Tilastokeskus.

Marin, M. (2001). Aikuisuus ja keski-ikäisyys. Teoksessa A. Sankari \& J. (toim.) Jyrkämä. Lapsuudesta vanhuuteen. Iän sosiologia. Tampere: Vastapaino. 225-265.

Moore, E. (2000). Aikuisena yliopistossa. Yliopisto-opiskelijoiden ikärakenne ja 30 vuotta täyttäneiden opiskelijoiden elämänkulku. Joensuun yliopiston sosiologian laitoksen julkaisuja 2.

Moore, E. (2003). Pitkä opintie. Aikuisiällä suoritettu yliopistotutkinto ja koulutuksellisen elämänkulun muutos. Joensuun yliopiston yhteiskuntatieteellisiä julkaisuja 61. Joensuun yliopistopaino.

Piesanen, E. (2005). Yliopisto-opiskelijaksi vaihtoehtoisin poluin. Näkökulmia ammatillisten ja avoimen yliopisto-opintojen kautta yliopisto-opiskelijaksi siirtymisestä. Koulutuksen tutkimuslaitoksen tutkimusselosteita 20. Jyväskylän yliopisto.

Rinne, R. \& Salmi, E. (1998). Oppimisen uusi järjestys. Uhkien ja verkostojen maailma koulun ja elämänmittaisen opiskelun haasteena. Tampere: Vastapaino.

Jauhiainen, A., Tuomisto, H., Alho-Malmelin, M., Halttunen, N. \& Lehtonen, K. (2003). Avoimen yliopiston opiskelija - kokovartalokuvasta eriytyneisiin muotokuviin. Turun yliopiston kasvatustieteiden tiedekunnan julkaisuja A:200.

Rinne, R. \& Jauhiainen, A. (2007). The meaning of lifelong learning, aging generations and knowledge society. In R. Rinne, A. Heikkinen \& P. Salo (eds.) Adult Education - Liberty, Fraternity, Equality? Nordic views on lifelong learning. Research in Educational Sciences 28. Finnish Educational Research Association. 105-124.

Roos, J. P. (1988). Elämäntavasta elämänkertaan. 
Jyväskylä: Gummerus.

Savioja, H., Karisto, A, Rahkonen, O \& Hellsten,

K. (2000). Suurten ikäluokkien elämänkulku.

Teoksessa E. Heikkinen \& J. Tuomi. (toim.)

Suomalainen elämänkulku. Helsinki: Tammi. 58-73.

Tilastokeskus 2007. Työvoima ja työvoimaan kuulumaton väestö 1989 - 2006 -> tietokantahaku (www.stat.fi -> Tuotteet ja palvelut -> Tilastotietokannat -> Työvoimatutkimus) luettu 16.4.2007.

Tilastokeskus 2005. 25-69-vuotiaat miehet ja naiset koulutustason, iän ja elävänä syntyneiden lasten määrän mukaan 31.12.2004 (Excel) (25.11.2005) (www.stat.fi -> Tilastot -> Tilastot aiheittain -> Väestö -> Väestörakenne -> Taulukot) (luettu 16.4.2007)

Tuomisto, J. (1997). Elinikäisen oppimisen teoreettiset ja historialliset lähtökohdat. Teoksessa Näkökulmia elinikäiseen oppimiseen. Elinikäisen oppimisen komiteanmietinnön (1997:14) liite. Helsinki: Opetusministeriö.

Turunen, K. E. (2005). Ikävaiheiden kriisit. Jyväskylä: Atena-kustannus.

Virtanen, M. (2005). Suuret ikäluokat sukupolvena. Teoksessa Karisto, A, (toim.). Suuret ikä- luokat. Tampere: Vastapaino. 197-207.

\section{Viite}

1. Aineisto liittyy Turun yliopiston Kasvatustieteiden laitoksella käynnissä olevaan Opetusministeriön rahoittamaan tutkimushankkeeseen "Avoin yliopisto ja aikuisten sisääntuloväylät yliopistojen tutkintokoulutukseen”, jossa tutkitaan aikuisten hakeutujien taustoja ja elämäntilanteita. Mukana tutkimushankkeessa ovat Risto Rinne, Arto Jauhiainen, Nina Halttunen ja Hanna Nori. Aineisto on laadittu yhteistyössä Valtakunnallisen hakijarekisterin ja Tilastokeskuksen kanssa.
Artikkeli saapui toimitukseen 28.7.2006. Se hyväksyttiin julkaistavaksi 21.6.2007. 